\title{
下顎骨に発生した中心性巨細胞肉芽腫
}

小川至則・岡本哲治・伊東映子

細川敬司・阪本知二・高田和彰

\section{Central giant cell granuloma in the mandible}

\author{
Yoshinori Ogawa - Tetsuji Окамотo - Akiko Iтон \\ Keiji Hosokawa $\cdot$ Tomoji Sakamoto $\cdot$ Kazuaki TAKada
}

Key words: mandible (下顎骨), central giant cell granuloma（中心性巨細胞肉芽腫）

FGF（線維芽細胞增殖因子）

\section{緒言}

われわれは，下顎骨中心性巨細胞肉芽腫之診断した症 例を経験したので，との治療経過とともに同症例の免疫 組織学的所見について報告する。

\section{症例}

患 者: 28歳 女性.

初 診: 平成 2 年 5 月回日.

主 訴: 左側下顎歯肉の腫脤.

既往歴：特記事項なし.

家族歴：特記事項なし。

現病歴: 平成 2 年 5 月曰日, 左側下顎大曰歯相当部に 疼痛を自覚し某歯科を受診. 同歯科にて, $\sqrt{8}$ の抜歯途 中, 出血量が多くまたX線検査により左側下顎骨にX線 透過像を認めたため抜歯を中止, 紹介により当科を初診 した.

現 症：顔貌は左右非対称. 左側下顎角部に骨様硬の 膨隆を触知．同部の表面皮䖉は正常で三叉神経第 $\mathbb{I I}$ 枝の 知覚異常叔よび所属リンパ節の腫脹は認めなかった。

口腔内は $\mid \overline{8}$ の残根を認めた. 左側下顎歯慒歯肉の表 面粘膜は正常で $\sqrt{5}$ 臼後部にわたり䫅, 舌側飞骨様硬 の膨隆を認めたが羊皮紙様感は認めなかった。

$\mathbf{X}$ 線所見：パノラマ写真に执いて $\sqrt{5}$ 根尖から下顎角 部まで, 上方は下顎切痕にわたり境界の比較的明瞭な多 胞性X線透過像を認めた（写真1）。顔面正面, 咬合型 飞执いて左側下顎骨体部の頓舌的骨膨隆を認めた。歯根 の吸収は認めなかった。 CT 所見では, 内容物は脂肪様 組織拉よび軟組織で充満していると考えられた。 また骨

広島大学歯学部口腔外科学第 1 講座

（主任：高田和彰教授）

Department of Oral and Maxillofacial Surgery I, School of Dentistry, Hiroshima University (Chief:

Prof. Kazuaki Takada)

受付日：平成 3 年 11 月 20 日

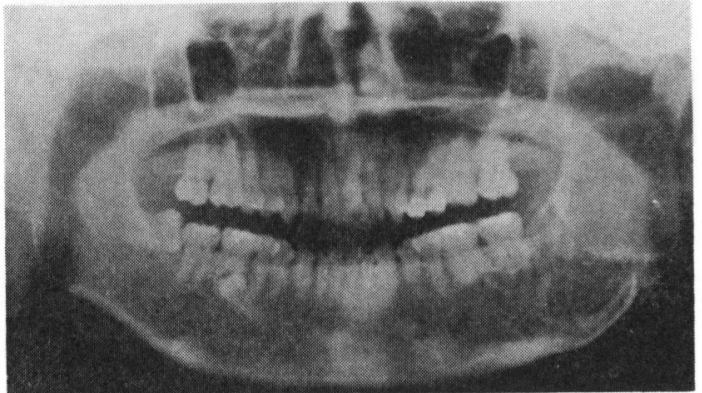

写真 1 初診時のパノラマ写真

皮質の破壊は認めなかった。

血液検查所見：アルカリホスファターゼ (ALP) 值 $(259 \mathrm{IU} / \mathrm{d} l)$ の軽度上昇, 血小板数 $\left(41.6 \times 10^{4}\right)$ の増 加を認めた，血清カルシウム，リン，副甲状腺ホルモン (PTH-C) レベルは正常範囲内であった.

臨床診断 : 下罘腫瘍の疑い.

処置および経過 : 平成 2 年 6 月日日, 局麻下に $\sqrt{8}$ の 拔歯ならびに同部より生検を施行した。そ結果，巨細 胞内肉芽腫と確定診断された。

平成 2 年 6 月曰日, GOE 全麻下に肉芽腫搔爬括よび $\mid 567$ 抜歯術を施行した。肉芽は暗紫色, 弾性軟で一部 脂肪を含み易出血性であった。 $\sqrt{5}$ 相当部では下歯槽管 周囲に肉芽が存在し，完全掻爬はできなかった，掻爬終 了後は搔爬腔にガーゼを拽入し手術を終了した。

平成 2 年 10 月, 搔爬腔顐側内面に再び肉芽の増殖を認 めたため, 平成 2 年10月日日 GOE 全麻下に再搔爬術 を行った。現在, 搔爬腔は肉眼的に正常粘膜で被われ, X線的にも骨の新生像が認められ良好である.また ALP 值 $(158 \mathrm{IU} / \mathrm{d} l)$, 血小板数 $\left(33.9 \times 10^{4}\right)$ も正常化した.

免疫組織学的検索 : 同組織をアセトン固定後パラフィ ン包埋を行い $6 \mu \mathrm{m}$ の切片を作製した. ベクタスタチン $\mathrm{ABC}$ キット (フナコシ KK) を用い, 一次抗体として 


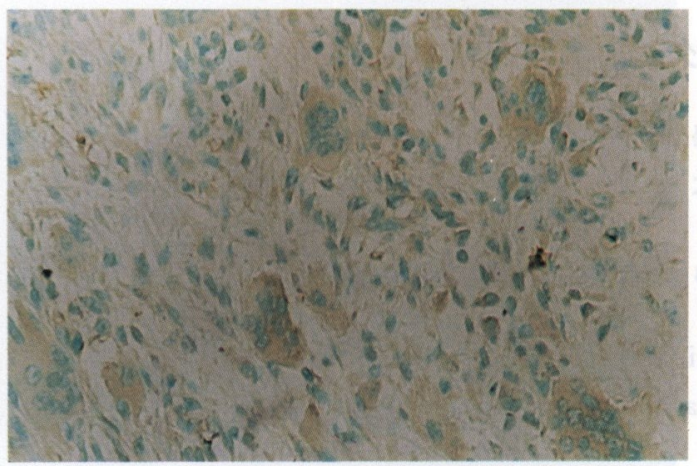

写真 $2 \mathbf{A}$ 抗 acidic FGF モノクローナル抗体によ る免疫組織学的所見 $(\times 200)$

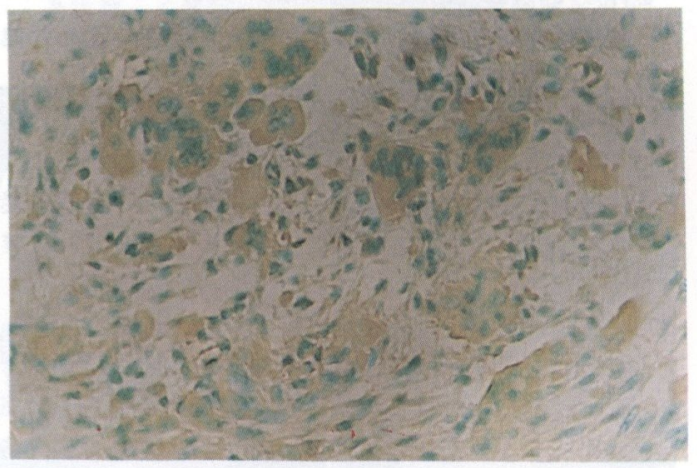

写真 2B 抗 basic FGF モノクローナル抗体によ る免疫組織学的染色所見 $(\times 200)$

抗 acidic fibroblast growth factor (aFGF) ならびに抗 basic FGF モノクローナル抗体を用い免疫染色を行っ た（写真 $2 \mathbf{A}, \mathbf{B}$ ).

\section{考察}

口腔領域に出現する巨細胞性病変は, 巨細胞腫, 巨細 胞肉芽腫の他に褐色腫, ケルビズムがある ${ }^{1)}$. 自験例で は諸検査により副甲状腺機能異常は否定できた。 また家 族歴に特記すべき事項はなくケルビズムも否定された。

石川 ${ }^{1)}$ は巨細胞肉芽腫では巨細胞の数が巨細胞腫より 少なくまた，その大きさや分布が不規則であるとしてい る.また，Abrams ら ${ }^{2)}$ は巨細胞の大きさが巨細胞腫で は大きく，核の数も多いことで両者を区別しうるとして いる. 自験例では, さまざまな大きさの多核巨細胞と単 核の紡錘形あるいは卵円形をした間葉系細胞から構成さ れ, 結合組織の占める割合が比較的大きく，巨細胞の分 布が不規則であり，その核の数も少なく異型性を示して いなかった。また著明な炎症細胞浸潤を認めたことか ら，巨細胞肉芽腫と確定診断した.
$\mathrm{Jaffe}^{3)}$ は本疾患の発症原因として局所の外傷，出血な ぞに対する修復過程を挙げている。一方, Bernier ${ }^{4)}$ は歯 の形成の関与や，歯原性の間葉組織由来も考えられると している. 自験例に扣いてこれらの原因は否定された。 一方, 西川 ${ }^{5)}$ は妊娠の経過とともに病変の急速な増大 を認め，妊娠と巨細胞肉芽腫との関連を示唆している. 自験例でも初診 1 年前に出産の経験があり, 妊娠との関 連は否定できなかった。

巨細胞肉芽腫は多核巨細胞とその周用の豊富な血管組 織, 肉芽組織から構成されている。一方, 近年血管新生 あるいは肉芽形成に $\mathrm{FGF}^{6)}$ が重要な働きをしているこ とが示唆されている，aFGF，bFGF に対するモノクロ 一ナル抗体を用いた免疫組織学的検索の結果, 多核巨細 胞に打いてこれら因子が強く発現されていることがあき らかとなった。したがって，多核巨細胞がこれら因子を 産生することにより周囲組織での血管新生や肉芽形成を パラクライン的に促進している可能性が考えられた。 ま たわれわれは，骨芽細胞や破骨細胞に拈いてもこれら因 子が強く発現されていることを見い出して扣り（未発 表), 多核巨細胞が骨母細胞由来である可能性が示唆さ れた。

\section{結語}

下顎骨に発生した中心性巨細胞肉芽腫を経験し，その 治療経過とともに同組織の免疫組織学的所見について検 討した. 術後より約 1 年を経過した現在再発なく経過良 好である.

\section{引用 文 献}

1) 石川梧朗, 秋吉正豊, 他 : 口腔病理学 II. 永末書 店, 京都, 1982, 563-570頁.

2) Abrams, B. and Shear, M.: A histological comparison of the giant cells in the central giant cell granuloma of the jaws and giant cell tumor of the long bone. J Oral Pathol 3: 217-223 1974.

3) Jaffe, H.L.: Giant cell reparative granuloma, traumatic bone cyst and fibrous(fibro-osseous) dysplasia of the jaw bones. Oral Surg 6: 159-175 1953.

4) Bernier, J.L. and Cahn, L.R.: The peripheral giant cell reparative granuloma. J Am Dent Assoc 49: 141-148 1954.

5）西川英次, 寶田 博, 他：妊娠中に急速な顎骨 破壊像をきたした巨細胞性病変の 1 症例(抄). 日口外誌 34：2906 1988.

6) Burgess, W.H. and Maciag, T.: The he parin-Binding (Fibroblast) growth factor family of proteins. Annu Rev Biochem 58: 575-606 1989. 